\title{
SOBRE LUTA, EDUCAÇÃO E TRABALHO NO CAMPO: UM OLHAR SOBRE OS BOLETINS DA LIGA CAMPONESA DE GALILEIA
}

\author{
FABIANA FERREIRA NASCIMENTO DE SOUZA ${ }^{1}$ \\ FABIELE STOCKMANS DE NARDI ${ }^{2}$
}

Universidade Federal de Pernambuco

Programa de Pós-Graduação em Letras

Av Professor Morais Rego, 1235. 50670-420. Recife, PE - Brasil

$\underline{\text { fabiana nucelyahoo.com.br }}$ fabielestockmans@gmail.com

\begin{abstract}
Resumo. Neste trabalho, observamos os modos de dizer do Camponês sobre si e suas lutas produzidos no jornal "Liga" e no Boletim "Carta de Alforria do Camponês", vistos como respostas a um discurso "sobre" (MARIANI, 1998) difundido por jornais da época que, pela repetição de um modo de dizer o camponês, produzia a criminalização de sua luta. O jornal e o Boletim são espaços de resistência que traduzem um desejo de instrução do camponês, na luta pelos sentidos das palavras, reconhecendo-se, como nos ensina Pêcheux ([1975] 1995), que as contradições ideológicas, que se marcam na/pela língua, resultam das relações sempre contraditórias entre os processos discursivos que, por sua vez, estão atravessados pelas relações de classe.
\end{abstract}

Palavras-chave: discurso; campesinato; luta.

\begin{abstract}
This study observes the ways farmers talk about themselves and about their fight produced in the newspaper "Liga" and the Bulletin understood as their answers to a discourse "about" (MARIANI, 1998) spread by the newspapers from that time that, by repetition, produced criminalization of their fight. The newspaper and the Bulletin are spaces of resistance that translate a desire for Clarification of the peasant, in the struggle for the senses of words, recognizing, as Pêcheux ([1975] 1995) teaches us, that the ideological contradictions, that are marked in / by the language, result from the always contradictory relations between the discursive processes that, in turn, are crossed by the class relations.
\end{abstract}

Keywords: discourse; peasantry; fight.

\footnotetext{
${ }^{1}$ Mestre em Letras pela Universidade Federal de Pernambuco.

2 Doutora em Letras pela Universidade Federal do Rio Grande do Sul. Docente e pesquisadora na Universidade Federal de Pernambuco, atuando nos cursos de Graduação, na área de Língua Espanhola, e Pós-graduação em Letras, na área de Linguística.
} 


\section{INTRODUÇÃO}

"No curso de toda a história da civilização, o camponês sempre carregou o fardo mais pesado. Não há exagero em afirmar que durante milênios e até nossos dias, o camponês vem ocupando o espaço existente entre a besta de carga e o senhor das terras" (JULIÃO, 1970 , p. 2-3). As palavras de Julião, na década de 70 do século passado, remetem ao espaço de abandono/exploração em que sempre esteve situado o camponês, um entrelugar difícil de descrever e prenhe de contradições...

Diante dessas contradições, compreendemos a unidade camponesa como a que "leva a uma economia sem determinações derivadas das grandezas socialmente estabelecidas, seja do lucro, seja da renda da terra, seja do salário" (COSTA, 1994, p. 12). Não queremos com isso afirmar que o trabalho assalariado no campo não exista ${ }^{3}$. Sabemos que existe, porém ele não se tornou majoritário com o desenvolvimento do capitalismo, até o momento histórico que por nós será analisado - é importante lembrar que o nosso trabalho de pesquisa compreende pouco mais de uma década, desde meados dos anos 1950 até 1964. Alinhamo-nos com Chayanov ([1925] 1974) ao compreender que a família é o fundamento da "empresa camponesa", tal unidade é, ao mesmo tempo, de produção e de consumo, "a família e as relações que dela resultam têm que ser o único elemento organizador da economia sem assalariados" (ibidem, p. 9).

Neves (1985) ressalta que a sociedade camponesa é composta por estratos de camponeses ricos ${ }^{4}$, médios e pobres e todas essas camadas se subordinam, em diferentes níveis, ao Estado. $\mathrm{O}$ acesso à terra para os camponeses pobres é dificultado pela existência de grandes latifúndios nas mãos de poucos camponeses ricos. Estes têm uma propriedade de área de terra superior à capacidade de trabalho dos membros da família. A solução, pois, encontrada por eles, para explorar a maior extensão de terras possível, é a parceria, exigindo do camponês pobre manter-se pela inserção dos filhos produtivos como parceiros $^{5}$. Existe, portanto, um aparente equilíbrio nesta relação, no entanto, no momento

\footnotetext{
${ }^{3}$ Há vários pesquisadores que se ocupam com a reflexão sobre o grau de imersão dos camponeses na economia de mercado, discussões que, neste artigo, não poderemos trazer em sua completude. Importa-nos, no entanto, frisar que, em nossa compreensão, ainda que não estejam os camponeses isolados/protegidos/alheios à lógica do capital, eles não se deixaram tragar pelas engrenagens do capitalismo. Alfred Kroeber nos dá a definição antropológica de um camponês, dizendo: “Os camponeses são decididamente rurais - no entanto vivem em relação com as cidades-mercados: eles formam um segmento de classe de uma população maior que geralmente compreende também centros urbanos, às vezes capitais metropolitanas. Eles constituem sociedades parciais com culturas parciais. Não têm o isolamento, nem a autonomia política e a autossuficiência das populações tribais; mas suas unidades locais retêm muito de sua antiga identidade, integração e ligações com solos e cultos" (KROEBER, 1948, p. 284 em FORMAN, 2009, p. 10). Os componentes dessa definição foram ampliados com o tempo por "escritores que enfatizaram, em graus variados, os critérios culturais, estruturais, sociais, econômicos ou políticos mencionados na breve definição de Kroeber." (ibidem, p. 11). A diversidade de tipos de camponeses constitui uma parte do sistema sócio-político-econômico rural que é parte de um sistema social mais abrangente.

${ }^{4}$ Não vamos tratar dessa designação neste momento, por uma questão de restrições do espaço disponível nesta publicação. Tomamos, então, a designação de Neves como parâmetro para descrever as relações de trabalho que se estabeleciam no campo entre trabalhadores e donos de terra. No entanto, importa-nos dizer que a designação "camponês", no conjunto de trabalhos realizados por nós, não se refere ao denominado "camponês rico". A este, preferimos nos referir como latifundiário.

5 "Parceiro, como ninguém ignora, é o camponês que arrenda um pedaço de terra mediante a entrega obrigatória ao senhor de parte do que produz. O senhor é o proprietário, o dono das terras, o latifundiário, que, em várias regiões do Brasil, e no Nordeste, em particular, recebe a designação genérica de coronel"
} 
em que há a transferência de excedentes entre as unidades de produção, expõem-se mecanismos de exploração como importantes características dessa relação de "parceria".

Diante dessa pequena mostra, na relação de "parceria", enxergamos que, aos camponeses pobres, resta-lhes desenvolver as mais duras tarefas, quase sem esperança de recompensa satisfatória, digna do seu esforço. Mesmo assim, tardaram em tomar atitudes que fizessem minimamente valer os pactos firmados entre eles e os latifundiários. "Os camponeses encontram-se numa posição especialmente desvantajosa na passagem do reconhecimento passivo de injustiças para a participação política capaz de repará-las" (WOLF, 1976, p. 94).

É possível entender que, para os camponeses, engajar-se numa luta duradoura seja difícil por diversas razões. Daremos ênfase ao fato de que, se o camponês sempre foi afastado de todo o processo de tomada de decisão que não excedesse os limites de produção, nada é mais previsível que ficar calado e subjugado à vontade dos que o oprimem, pois sua integração no regime societário capitalista os torna sujeitos aos detentores do poder que são externos ao estrato camponês.

Compreendemos, porém, que não há imposição de poder que não encontre resistência e, se possuir os meios de trabalho que lhes possibilitem sobreviver, sem ter a necessidade de vender sua força de trabalho no mercado capitalista, é uma das condições de existência do campesinato, diversos gestos de resistência que visam garantir ao campesino sua possibilidade de (re)existir nessa sociedade, marcam a história do campesinato. Um desses movimentos é o da reforma agrária que, como dizia Francisco Julião, tem que ocorrer, "na lei ou na marra" (JULIÃO, 1962, p. 73), luta que teve, nas Ligas Camponesas, uma de suas expressões mais fortes.

Neste trabalho, lançaremos um olhar sobre a Liga Camponesa de Galileia, mais especificamente, para os modos de dizer sobre/de os camponeses e suas lutas produzidos no boletim "Carta de alforria do camponês" e no jornal "Liga", aqui entendidos como respostas desses sujeitos a um discurso "sobre" (MARIANI, 1998) difundido pelos jornais da época que, pela repetição de um modo de dizer esse trabalhador e seus movimentos, produzia a criminalização de sua luta.

\section{A LIGA CAMPONESA DE GALILEIA}

Como dissemos acima, diversos gestos de resistência marcam o campesinato, que tem nas organizações camponesas um capítulo importante de sua história, organizações que tomaram forma escrita com o surgimento, primeiramente, dos sindicatos rurais, e, em seguida com a formação da Liga Camponesa de Galileia, em 1955. Com ela, a luta pela terra começou a ganhar vida, como semente de um campesinato em modificação que frutificou no Brasil com movimentos posteriores.

Ocupamo-nos, neste trabalho, da chamada segunda fase das Ligas Camponesas que surgem, contemporaneamente ao sindicato rural, como resultado da ruptura entre o lavrador e a propriedade dos meios de produção. De acordo com Octávio Ianni (1976, p.

(JULIÃO, 1970, p. 24). A medida da parceria é sempre fixada pelo dono da terra. Pode representar a metade, a terça parte ou a quarta parte de tudo aquilo que o camponês produzir. 
154), "a liga camponesa corresponde muito mais diretamente às reivindicações do próprio trabalhador rural. Ela nasce como uma reação desse trabalhador às condições econômicas e sociais adversas em que se encontra, enquanto produtor". As Ligas Camponesas são entendidas então:

como organização, se caracterizam pela forma centralizada de atuação. Trata-se de uma associação, o nome pouco importa, que organiza delegacias em qualquer lugar onde haja camponeses. A sede central deve ficar na capital do Estado ou na maior cidade da região em que se funde. Porque aí estão a classe operária, os estudantes, os intelectuais revolucionários, a pequena burguesia, uma justiça mais avançada ou menos reacionária do que aquela que se deixa sufocar, numa cidadezinha do interior, sob o peso do latifúndio. (JULIÃO, 1962, p. 47)

Apesar de Julião dizer que "o nome pouco importa", foram as semelhanças com as ligas do partido comunista brasileiro que fizeram com que a própria mídia alcunhasse a Sociedade Agrícola e Pecuária de Plantadores de Pernambuco (legalizada por Julião) como Liga. Assim, tal sociedade logo se auto intitulou "Liga de Galileia". O intuito principal da Liga de Galileia era a luta pela reforma agrária que contemplasse os camponeses sem terra e os de pouca terra.

A essa demanda principal, vincularam-se os atos de resistência dos foreiros aos constantes aumentos do foro e à ameaça de expulsão. Em nome dessa luta, Paulo Travassos e José Ayres dos Prazeres (ambos líderes na organização e defesa da SAPPP), ao buscarem ajuda externa, encontraram-se pela primeira vez com Francisco Julião que passou a representar juridicamente os interesses dos foreiros e, juntamente com outros políticos, criaram um comitê interpartidário ${ }^{6}$, que funcionou como o embrião do Conselho Regional da SAPPP.

Até a criação do Comitê, quando as questões camponesas apareciam na imprensa conservadora, eram tratadas como caso de polícia e não de políticas públicas que visassem sanar os graves problemas dos camponeses. E foi, por intermédio dessa mesma mídia, que a SAPPP passou corriqueiramente a ser chamada de Liga para que fosse feita, de maneira automática, uma vinculação dos movimentos de luta pela terra a todo $o$ arcabouço de conhecidas "verdades" sobre os comunistas.

A partir da Liga de Galileia, muitas outras Ligas foram criadas e espalharam-se pelo Brasil inteiro. E, segundo Julião (1962), sempre que uma liga surgia, um novo ataque violento da imprensa da classe dominante se iniciava - como se ali estivesse:

[...] uma corja de bandidos e assaltantes... É obrigatório, nessa fase, para o redator policial, o registro com destaque de fatos deturpados, contendo insultos e calúnias contra os camponeses, sua liga e seus dirigentes. Todos são chamados de comunistas, carbonários, terroristas e agitadores. (idem, p. 31)

\footnotetext{
6 "O comitê político denunciava, nas tribunas parlamentares e na própria imprensa, a situação do Engenho Galileia, impedindo que a repressão se abatesse sobre os galileus. A ação desse comitê, que reunia membros de quase todos os partidos oposicionistas do Estado, dirigido então pelo PSD e controlado pelas oligarquias mais tradicionais no poder desde $1937 \ldots$ transformava em fato político os conflitos entre camponeses e proprietários rurais" (AZEVEDO, 1982, p. 62).
} 
Referia-se, Julião, aos constantes ataques aos camponeses e suas organizações, presentes em notas como a que reproduzimos abaixo:

\begin{abstract}
$\mathrm{SD} 1^{7}$
RIO, 6 (Meridional) - Toda a Zona Rural do Nordeste está correndo um grave risco, com a infiltração insidiosa e perseverante dos agentes comunistas através da instalação das chamadas "ligas camponesas", aparentemente destinadas a prestar assistência aos necessitados, mas constituindo, na verdade, focos de subversão que poderá explodir quando menos esperarmos - declarou hoje Dom Severino Mariano de Aguiar, Bispo de Pesqueira, em Pernambuco, que foi um dos principais coordenadores de bispos do Nordeste. (Jornal DIARIO DE PERNAMBUCO, terça-feira, 7 de abril de 1959, matéria de capa com continuação na página 10 do jornal)
\end{abstract}

\title{
SD 2
}

Título: BISPO DE PESQUEIRA: COMUNISTAS AGEM NO INTERIOR NORDESTINO. GRIFO NOSSO)

\section{ENTREVISTA DO BISPO}

O Sr. Eudes Costa leu e comentou da tribuna a entrevista concedida pelo Arcebispo de Pesqueira, Dom Severino Aguiar, prestada ao Globo, denunciando as manobras do credo vermelho através das ligas camponesas. (Jornal DIARIO DE PERNAMBUCO, quarta-feira, 08 de abril de 1959, Primeira Página. Pernambuco: região onde agem os vermelhos mais abertamente)

\section{SD 3}

RIO, 20 (Meridional) - Novo plano subversivo organizado pelos comunistas pernambucanos, segundo orientação do diretório central de Pernambuco, acaba de ser descoberto e comunicado ao serviço de informações do IV Exército, que já conhece todos os detalhes da ação a ser realizada.

Desta vez o campo de ação escolhido pelos vermelhos que agem na "frente agrária" foi o município de Garanhuns. De acordo com os documentos levados ao Exército, estão sendo projetados vários incêndios nos cafezais daquele município, visando a prejudicar a produção cafeeira de Garanhuns, agitando os agricultores e proprietários rurais possibilitando um clima propício à instalação de novas "ligas camponesas". (Jornal DIARIO DE PERNAMBUCO, terça-feira, 21 de abril de 1959. Capa: Novo Plano Subversivo Vermelho em Pernambuco)

Se observarmos as recorrências nos discursos que deslegitimam o movimento dos camponeses, veremos que neles se repete a referência aos movimentos como coisas de comunistas. A “infiltração insidiosa e perseverante dos agentes comunistas" encontra nas ligas o seu lugar, e o sentido de comunista se vê amarrado, nesses recortes, ao que gera ameaça, "um grave risco" representado por esses que, sob a aparente oferta de assistência aos necessitados, vêm, "na verdade", para instalar a subversão. Risco, subversão, infiltração insidiosa, credo vermelho, manobra, são esses alguns dos modos de dizer as

\footnotetext{
7 Vamos designar por SD, simplesmente, as sequências discursivas recortadas da mídia conservadora da época, com as quais trabalharemos nesse tópico. Nas análises que seguem, designaremos SD(L) e SD(B), respectivamente, as sequências trazidas do jornal Liga e do Boletim.
} 
ligas em sua estreita relação com o comunismo que se fazem presente nas notícias sobre o movimento.

Embora não seja nosso objeto central de análise neste artigo, os recortes acima nos ajudam a observar um trabalho de criminalização das ligas que se produz por sua vinculação aos sentidos de comunista/comunismo que se estabilizaram no imaginário brasileiro. Tratase de um forte e reiterado gesto de vinculação do comunista àquilo que ameaça, assusta, provoca desordem, (des)orienta. Um breve passar de olhos pelas SDs acima pode nos levar a um jogo com as palavras em que comunista está em relação direta com risco, infiltração insidiosa, subversão; as quais, por sua vez, apontam para as "ligas camponesas" e sua instalação como uma ameaça para a qual se deve estar atento. Tratase de um inimigo identificado, esse "credo vermelho" que todo mundo sabe o que é e a que vem, trabalho da ideologia, nos termos de Pêcheux ([1975] 1995, p. 160), "que fornece as evidências pelas quais "todo mundo sabe" o que é um soldado, um operário, um patrão [...]" um comunista... Evidências que produzem, sob a máscara da transparência da linguagem, um apagamento do "caráter material do sentido das palavras e dos enunciados" (Idem).

Entendemos que o que se observa, nesse rápido olhar para as SDs, é um movimento de estabilização em torno da palavra comunista/comunismo tal como o descreveu Mariani (1998, p. 107) em sua obra "O PCB e a imprensa: os comunistas no imaginário dos jornais 1922-1989”. Diz a autora:

[...] o fato é que o uso da palavra "comunismo" nos jornais, ao longo dos anos, para além de designar uma ideologia partidária, passou a determinar um sentido que, como já mencionamos, é sempre negativo. Hegemonicamente, a produção de sentidos para 'comunista' gira em torno de 'inimigo', o outro indesejável.

Em seu trabalho, Mariani (1998, p. 18) aponta que desde 1922, quando da fundação do PCB, comunistas e não-comunistas travam uma luta constante para tornar visíveis os sentidos de seus discursos e especialmente aqueles dos discursos de seus adversários. " $\mathrm{O}$ comunista é um inimigo", mostra a autora, ao falar dessa equação linguística a partir da qual se determina o lugar do comunista.

[...] as denominações citadas (de comunistas, comunismo) parecem significar para além delas próprias, num processo em que sentidos são retomados e sustentam um efeito de negatividade presente desde a fundação do partido no Brasil. São sentidos que se mantiveram (se mantém) reverberando ao longo dos anos. (Ibidem, p. 113)

Esse efeito de negatividade se constrói, como vimos, nas sequências reproduzidas acima, onde se diz dos comunistas e do perigo que representam para a sociedade. A ação "dos vermelhos" assombra "agricultores e proprietários rurais", colocando em alerta a sociedade para que se proteja do "inimigo identificado". Compreendemos que esse gesto de identificação da ameaça pelo qual se diz as Ligas e, em nosso caso, muito particularmente a Liga da Galileia, pode ser compreendida como um trabalho de construção discursiva do referente, pelo qual se produz, pela língua, as fronteiras precisas desse objeto a ser identificado. É por meio desse trabalho que se pode dizer, sem dúvida, quem são "eles" - os comunistas, o credo vermelho, os vermelhos - que agem, 
insidiosamente, os inimigos a quem "nós", que nos identificamos com os agricultores e proprietários rurais, devemos nos opor.

No Diário de Pernambuco, a exemplo do que acontece nas notas acima analisadas, o movimento da Liga de Galileia - e aqueles que dele fazem parte - vão sendo ditos pela identificação com os comunistas/o comunismo a partir da estabilização de sentidos negativos em torno dessas palavras. Eis aquilo que se repete não apenas sobre $o$ trabalhador, como também sobre os seus movimentos, reproduzindo a ideologia da classe dominante, "que não se torna dominante pela graça do céu... é pelo estabelecimento dos Aparelhos Ideológicos de Estado ${ }^{8}$ onde essa ideologia (a ideologia da classe dominante) é realizada e se realiza, que ela se torna dominante" (PÊCHEUX, 2014, p. 4).

O trabalho, então, da mídia conservadora da época, enquanto AIE da informação, que, por sua vez, reverberava os discursos cristalizados pela igreja católica (AIE religioso) sobre o comunismo/comunistas ${ }^{9}$ encontraria resistência materializada no Jornal "Liga". É esse o momento em que vemos a realização da luta de classes na disjunção entre a ideologia dominante e a ideologia dominada (PÊCHEUX, [1975] 1995).

\section{O JORNAL "LIGA"}

O que vimos anteriormente como um discurso sobre as ligas - que promovia a sua criminalização enquanto gesto de identificação desse "inimigo vermelho", que tomava forma no campo - pode ser explicado porque eram os jornais, então, a encarnação do discurso de seus financiadores.

Ao fazer essas considerações retomamos o que foi trabalhado por Mariani (1998) ao pensar o discurso jornalístico como um discurso sobre, ao apontar, entre outras questões, o fato de que o discurso da imprensa, longe de ser autônomo, responde a uma série de determinações. Diz a autora que "os discursos sobre são discursos que atuam na institucionalização dos sentidos, portanto, no efeito de linearidade e homogeneidade da memória" (ibidem, p, 60).

\footnotetext{
${ }^{8}$ Os Aparelhos Ideológicos do Estado são definidos por Louis Althusser como um certo número de realidades que são apresentadas sob a forma de instituições "distintas e especializadas" (ALTHUSSER, 1985, p. 68), funcionando através da ideologia. Ele elenca, entre outros, o sistema das diferentes Igrejas, como o AIE religioso, e a imprensa como AIE de informação. Neste trabalho, vemos que os preceitos inculcados nas "ovelhas" pela Igreja ganha reforço também na imprensa a fim de que se produza um consenso sobre o que é ser comunista, como os camponeses e suas lutas se tornam nefastos ao se associarem ao comunismo e como essas práticas precisam ser criminalizadas para que as classes dominadas e dominantes se mantenham em seus devidos lugares.

${ }^{9}$ As primeiras condenações papais aos comunistas são encontradas em Encíclicas que datam do século XIX. Esse era ainda um momento em que havia estreitos laços entre a Igreja Católica e o Estado, tempo no qual essas duas instâncias insistiam em ser unas, havendo, porém, a preponderância daquela sobre este. Estes são alguns exemplos do posicionamento da Igreja em relação ao comunismo: "[...] Mas não desconheceis, veneráveis irmãos, que os principais arquitetos dessa maldosa trama desejam empurrar os povos, agitados por qualquer doutrina perversa que aparecer, à subversão de toda a ordem das coisas humanas e a arrastá-los aos execráveis sistemas do novo socialismo e comunismo. [...]" (Encíclica Nostis et Nobiscum, 8 de dezembro de 1849). "[...] Com essas ímpias opiniões e maquinações esses homens enganadores objetivam principalmente fazer com que a saudável doutrina da Igreja católica seja totalmente afastada da instrução e educação da juventude, e os tenros eflexiveis ânimos dos jovens sejam miseravelmente contagiados e depravados por perniciosos erros e vícios de toda sorte. [...]"
} 
Como dissemos, estamos entendendo o discurso da mídia conservadora da época como um discurso sobre as ligas, no sentido que se constrói no trabalho de Mariani (1998), visto funcionar, esse discurso, como uma forma poderosa de criminalização dos camponeses e suas lutas ao convocar diferentes vozes para dizer sobre a ameaça que representavam. Esse discurso violento do latifúndio não ficou, no entanto, sem resposta.

À época, combateram-se os jornais da mídia corporativa com o jornal "Liga". Este, criado em 1962, trazia artigos e notícias relacionados com a vida dos camponeses e suas organizações mais ativas: as Ligas Camponesas e os Sindicatos rurais. Foi no Jornal "Liga" que a expressão do campesino pôde criar processos discursivos que davam significado às suas lutas e à resistência contra uma grande mídia que discursivizava os mesmos fatos, "traduzindo" o trabalho realizado pela Liga como um movimento de ameaça à ordem, a uma ordem suposta da qual fariam parte "agricultores e produtores rurais", que, designados como alheios às ligas, aparecem como aqueles a quem o "credo vermelho" ameaça sob a aparente organização de um espaço de assistência aos necessitados.

No entanto, as Ligas Camponesas, ao falar de si, pretendiam (e não sabem se lograram seu intento) humanizar o camponês, que entendemos como uma das formas de enfrentamento ao discurso dominante.

A LIGA CAMPONESA não existiria sem essa convivência que não é exclusivamente nossa, mas de um punhado de outros que, com maior ou menor entusiasmo, deram o que puderam com vistas ao mesmo objetivo: humanizar o camponês, ou seja, dar-lhes os instrumentos políticos indispensáveis para que ele se sinta um ser humano. (JULIÃO, 1969, p. 4-5)

Entendemos que há, nas palavras de Julião, um direcionamento bastante contundente para o sentido de humanizar com o qual trabalha, que é a oferta de "instrumentos políticos" considerados indispensáveis para que esse outro, o camponês, sinta-se um ser humano. Trata-se, nesse movimento de formação do sujeito na Liga, de um trabalho de conscientização política do camponês, que precisa reconhecer os seus direitos para, então, reconhecer-se como "ser humano" 10 . Nisso está, então, o jornal como instrumento que, para tanto, trazia, em suas seções, denúncias contra os desmandos do latifúndio, assim como, e, principalmente, poemas e artigos (entre outros gêneros) que se propunham a "educar" os quadros de filiados das Ligas, organizando-os politicamente.

Educar aparece, então, como palavra de ordem, e o jornal "Liga" é, para os intelectuais, um instrumento para a educação desejada para os camponeses. Por outro lado, é a própria educação um instrumento, algo que se faz para, como meio de se chegar à desejada organização dos camponeses. “....só conseguiremos impor essa organização por meio do estudo, pois é pelo estudo que se impregna o espírito revolucionário, uma ideologia nos

\footnotetext{
${ }^{10}$ Por uma questão de foco analítico, não poderemos, neste trabalho, mergulhar de forma mais profunda nessa questão, que, entendemos, se mostra fundamental para que possamos discutir as noções de convivência, humanização, educação, entre outras que aparecem no periódico "Liga". Cabe, no entanto, comentar que, nos escritos de Julião e outros intelectuais que falam sobre o movimento, pode-se vislumbrar um movimento de atribuição aos intelectuais dessa tarefa de "humanizar" que perpassa necessariamente a emancipação do camponês. Humanização que não se faz senão pela necessária tomada de consciência, por parte do camponês, de seu lugar como pessoa no espaço por ele ocupado (JULIÃO, 1969).
} 
homens que realmente querem a libertação de sua pátria" (JULIÃO, 2012, p. 212, grifo nosso).

Para os organizadores da Ligas camponesas, a tarefa de educar era tão importante que foi criada a Comissão de Educação das Ligas com o intuito de promover atividades constantes em favor do estudo marxista-leninista "capaz de forjar verdadeiros revolucionários" (JULIÃO, 1969, p. 527). O Jornal Liga tornou-se um dos espaços onde discursos de caráter injuntivo estavam presentes conclamando os companheiros a se engajarem na luta revolucionária que perpassaria necessariamente a "educação", mas não, a essa altura, uma educação apenas formal e, sim, uma educação "na teoria marxistaleninista" (JULIÃO, 2012, p. 212) em que surgiriam "novos quadros conscientes, capazes de corrigir, dirigir e levar à prática as grandes tarefas da nossa revolução" (Idem).

O Jornal Liga - que simbolizava os anseios das Ligas Camponesas - atribuía ainda à educação a tarefa de formar homens e mulheres "responsáveis, esclarecidos, corajosos e honestos" (JULIÃO, 2012, p. 213) que pudessem analisar dialeticamente as situações que se apresentassem. Entendia-se que, dessa forma, seria possível que esses sujeitos superassem a necessidade de mediação dos intelectuais que auxiliavam na organização do movimento de luta pela reforma agrária radical, assumindo o protagonismo de suas vidas e de suas lutas.

O jornal aparece, então, como um espaço em que comparecem as vozes dos intelectuais, preocupados em educar o camponês, mas também dos camponeses, que encontram um lugar para falar de si e aos seus. Vejamos, então, como isso se materializa nos escritos da Liga:

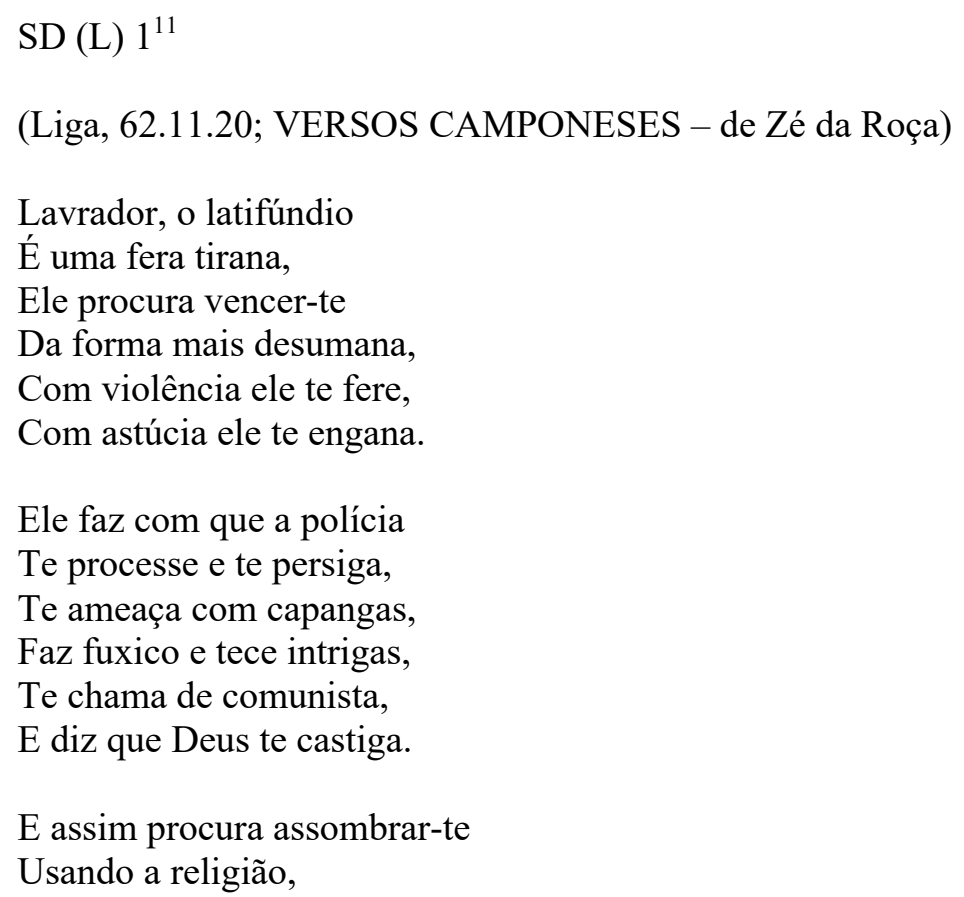

\footnotetext{
${ }^{11}$ Optamos, nesse momento, por reproduzir os textos na íntegra ou em fragmentos maiores, como forma de apresentar o modo de organização do Jornal e as temáticas mais recorrentes, que tomamos como exemplares das trajetórias argumentativas que vão ser assumidas no periódico em seu trabalho de combater um dito em outro lugar sobre o camponês e, ao mesmo tempo, educar(se) para a luta.
} 
Mas Deus não castiga o homem

Que luta pelo seu pão

Deus como pai está contigo

Condenando a escravidão.

Não ligue essa ameaça, Que vem da boca do padre Não creias no homem rico, Que te tomou por compadre, Quer conquistar tuas filhas, Quer iludir a comadre.

Várias são as seções do Jornal "Liga" que se preocupam declaradamente com a educação dos camponeses. Usa-se o espaço dos versos para cumprir o papel, ao qual se propõem Julião (2012), o de elevar a consciência dos camponeses, dando-lhes sustentação para aprimorar a sua organização.

Tomamos a $\mathrm{SD}(\mathrm{L}) 1$ como representativa de um movimento recorrente no jornal, o de marcar, para o camponês, o seu lugar na relação aos outros sujeitos com os quais divide o espaço do campo. Para marcar a divisão da sociedade de que faz parte, nos versos, convoca-se o lavrador - um tu, com quem se fala - a desconstruir a imagem do latifundiário - esse ele, de quem se fala -, usando para isso o recurso da personificação (que toma o latifundiário pelo latifúndio).

Pode-se dizer, então, que se produz, inicialmente, em SD(L)1 uma marcação dos lugares que ocupam esse eu que fala - de um lugar de esclarecimento/educação - o tu e o ele. Lavrador, é contigo que eu falo, diz o sujeito que enuncia, tu que és ferido, enganado, perseguido, processado, ameaçado, chamado de comunista. Quem faz isso contigo não sou eu, que estou aqui, ao teu lado, é ele, o latifúndio, essa fera tirana que fala pela boca do padre e do homem rico, que te fazem acreditar num Deus que te castiga. Pela marcação desses lugares, o sujeito que enuncia faz trabalhar, então, o seu dizer, pelo avesso do discurso dominante, colocando exatamente no lugar de a possibilidade de um efeito de sentido outro para o dito.

Ao falar para/com o camponês a partir do espaço da Liga, há, na construção dos versos, um movimento de contra-argumentação que se dá na luta pelos sentidos das palavras, num trabalho de deslocamento da imagem sobre os lugares e os sujeitos que o ocupam para ressignificar o dito assim, em outro lugar, a partir de uma posição-sujeito de "homem esclarecido" inscrita na formação discursiva (doravante FD) dos camponeses. É no interior dessa FD que se constrói a possibilidade de dizer quem são eles, quem sou eu, que aqui falo, quem és $t u$, que eu convoco a se identificar com a luta para reconhecer quem é teu "verdadeiro inimigo", que é aquele que ameaça e fere, explora e ilude, ainda que se faça de "compadre".

É, portanto, pela torção ${ }^{12}$ do discurso que se faz a resposta à criminalização do trabalho e das lutas dos camponeses, construindo-se um dizer em que é pela denúncia dos abusos

12 Ao usarmos torção, neste artigo, nos referimos não à deformação de um sentido que poderia ser supostamente o "literal" ou "correto", mas sim ao movimento pelo qual, ao apropriar-se do discurso de outrem, de suas palavras, o sujeito produz dobraduras nesse dizer, como se o fizesse "girar" no sentido contrário ao que se orientava. 
cometidos contra os camponeses que se responde ao que circula como dominante sobre o movimento camponês.

O trabalho com esse corpus nos permite, até o momento, pensar na existência de pelo menos duas FDs em conflito que atravessam, no período em análise, o discurso de/sobre as Ligas Camponesas de Galileia e que denominamos, aqui, FD dos camponeses e FD dos latifundiários. É no interior dessas FDs que vão se construindo os limites de sentido para as palavras em circulação sobre o campo e suas lutas, pois, como diz Pêcheux ([1978], 2011, p. 272), palavras, expressões, enunciados produzem diferentes sentidos de acordo com a posição da qual são enunciadas". É portanto, a partir de tomadas de posição no interior dessas FDs que vamos saber o que é violência, educação, comunismo; quem é Deus, quem é o patrão, quem somos nós, eu e tu, sobre quem se fala no jornal da capital, que queremos falar, aqui, no nosso jornal.

Se pensamos, conforme Pêcheux e Fuchs ([1975] 1997, p. 166-167) que as FDs "determinam o que pode e deve ser dito [...] a partir de uma posição dada numa conjuntura, isto é, numa certa relação de lugares no interior de um aparelho ideológico", considerando, é claro, a necessária percepção sobre a fragmentação e a heterogeneidade constitutivas do que chamamos de forma-sujeito de uma FD, vamos compreender que as possibilidades de dizer sobre o lavrador, o latifúndio, sobre Deus e o comunismo, nos diferentes recortes em análise, necessariamente precisam ser compreendidos como movimentos de tomada de posição no interior de uma FD. Portanto, é um jogo com os lugares, no discurso, que permite essa torção de que falamos, e que colocam em suspenso os sentidos que vêm de outro lugar, desse discurso do outro que se coloca como dominante.

[...] toda tomada de posição, toda identificação com uma forma sujeito implica resistência tanto a esse lugar como aos discursos outros que o atravessam, que contradizem os saberes da FD ou os negam, provocando rupturas. Desse modo, a tomada de posição do sujeito no discurso que o leva a se contraidentificar ou se desidentificar também faz parte de um movimento de resistência, previsto no ritual (com falhas) e no trabalho de reprodução (resistência-revolta-revolução) transformação "da luta ideológica e política de classes" (PÊCHEUX, 2009b, p. 280). (DE NARDI; NASCIMENTO, 2016, p. 88)

Nesse trabalho de "esclarecimento" do camponês comparece, ainda, segundo nossa leitura, um jogo com o imaginário sobre os lugares sociais que ocupam os sujeitos, um tensionamento de um imaginário que se coloca como dominante apontando para a relativização do peso da palavra vinda desses lugares. Merece especial atenção, nesse caso, o que se diz sobre o comunismo e a religião. Ao jogar com o dito nos versos da $\mathrm{SD}(\mathrm{L}) 1$, poderíamos apontar para algumas reformulações possíveis. Teríamos, então:

Comunista, Deus castiga (diz ele, que te ameaça pela boca do padre)

mas

Deus não castiga quem luta pelo seu pão, porque como pai, Deus está contigo (que lutas pelo teu pão) e condena a escravidão (que ele perpetua). 
então....

Se comunista é aquele que luta pelo seu pão, e Deus está com quem luta pelo seu pão, então Deus está com o comunista. (e, portanto, não está com ele).

Habita no discurso do camponês esclarecido a certeza de que chamar os camponeses de comunistas é um instrumento de opressão do qual eles precisavam se livrar: "Te chama de comunista, / E diz que Deus te castiga. / E assim procura assombrar-te / Usando a religião,". Esse discurso responde de forma direta ao que encontramos no primeiro conjunto de sequências discursivas, que designava os camponeses como: "comunistas pernambucanos" e "agentes comunistas", procurando desqualificar o sujeito pela vinculação dele mesmo e de sua luta ao imaginário sempre negativo criado em torno das designações comunismo/comunista. Em lugar, no entanto, de trabalhar diretamente sobre essa designação, demasiadamente marcada por esse trabalho de criminalização do sujeito comunista, é ao convocar a figura de Deus que a argumentação se constrói nesses versos promovendo, como dissemos, por um movimento de torção, o deslocamento dos sentidos construídos sobre os lugares, nesse caso, de Deus e comunista. É na torção da imagem de Deus e do comunismo que se desfaz a conformação nefasta da luta camponesa disseminada pela mídia conservadora:

\begin{tabular}{|l|l|}
\hline \multicolumn{1}{|c|}{ FD do Latifúndio } & \multicolumn{1}{c|}{ FD dos Camponeses } \\
\hline Deus que castiga & Deus como pai presente \\
\hline $\begin{array}{l}\text { Comunismo subversivo condenado por } \\
\text { Deus }\end{array}$ & $\begin{array}{l}\text { Comunismo como luta contra a escravidão } \\
\text { do latifúndio }\end{array}$ \\
\hline
\end{tabular}

Althusser (1985, p. 71) afirma que "os aparelhos ideológicos de Estado funcionam principalmente através da ideologia e secundariamente através da repressão, seja ela bastante atenuada, dissimulada, ou mesmo simbólica." e, para responder às sanções de ameaças e castigos que se fundem nas figuras do latifundiário e da Igreja, no AIE representado pela mídia conservadora, o discurso do campesinato busca desmascarar o padre e o homem rico: é na Igreja que o padre ameaça as ovelhas - ao dizer que a luta é coisa de comunista; é na Igreja que o latifundiário toma o pobre por compadre a fim de iludir a comadre e as filhas - numa clara alusão à exploração sexual. No entanto, ao mesmo tempo que desmascara o padre e o que ele representa, preserva a imagem de Deus, subvertendo-a.

Enfim, o plano subversivo organizado pelos comunistas, as manobras do credo vermelho, as infiltrações insidiosas e perseverantes dos agentes comunistas, os focos de subversão que são formulações recorrentes no discurso do latifúndio - dão lugar, no discurso do camponês, à luta pelo pão, abalizada pelo Deus que condena a escravidão imposta pelo latifúndio (ainda que não se possa, no entanto, dizer (se) 'comunista'13 ao camponês).

${ }^{13}$ Essa relação entre os comunistas e Deus, os camponeses e a religião, a separação entre Deus e a Igreja, entre outras questões que se situam na mesma ordem do dizer, se mostram, no conjunto do corpus de que 


\section{SOBRE A LUTA COM/PELAS PALAVRAS: OS BOLETINS}

A imprensa da classe dominante, como nos disse Julião (1962), não tardava em caluniar e insultar os dirigentes das Ligas Camponesas quando uma delas surgia. Todos eram chamados de carbonários, terroristas, agitadores... e esses ataques duravam meses. Tudo isso explicava as razões pelas quais a sociedade naturalizava a violência do latifúndio.

Em resposta a esse discurso e com o desejo de "despertar, atrair, unir e organizar os camponeses em Ligas" (JULIÃO, 1962, p. 33), foram escritos em linguagem simples e estrutura injuntiva vários Boletins, dentre eles a "Carta de Alforria do Camponês". Esses escritos eram portadores de sentidos outros para palavras e expressões que buscavam criminalizar a luta dos camponeses pela terra.

Vejamos o que nos mostra a SD (B) 2, que reproduzimos abaixo:

$\mathrm{SD}$ (B) 2

(CARTA DE ALFORRIA DO CAMPONÊS, In: Stédile, 2012, p. 197)

Daqui do Recife, de Pernambuco, o berço das Ligas Camponesas, eu te mando esta carta, camponês do Brasil, na esperança de que ela chegará à tua casa.

Tu és com os teus irmãos quase todo o Brasil. És tu quem mata a nossa fome. E morre de fome. És tu que nos veste. E vives de tanga. Dás o soldado para defender a pátria. E a pátria te esquece. Dás o capanga para o latifúndio. E o capanga te esmaga...

Com a violência ele te faz medo. Com a astúcia ele te engana. A violência é o capanga. É a polícia. É a ameaça de te jogar fora da terra. De te pôr a casa abaixo. De te arrancar a lavoura. De te matar de fome. De te chamar de comunista e dizer que Deus te castiga. Como se pudesse haver maior castigo do que esse em que tu vives. Acorrentado ao latifúndio. Em nome de uma liberdade que não é a tua liberdade e de um Deus que não é teu Deus.

SD (B) 3

(CARTA DE ALFORRIA DO CAMPONÊS, In: Stédile, 2012, p. 202/203)

Muitos são os caminhos que te levarão à liberdade. Liberdade quer dizer terra. Quer dizer pão. Quer dizer casa. Quer dizer remédio. Quer dizer escola. Quer dizer paz. Eu te apontarei esses caminhos. Mas eu te digo e repito: não adianta a viagem se tu fores sozinho. Convida teu irmão sem terra ou de pouca terra...

Há séculos que é assim. Já se gritou demais. E nada. É que o grito veio de cima. De bem poucas vozes. Não abala o latifúndio, que é surdo e tem o coração de pedra. É preciso que o clamor venha de baixo. De ti. Com todos os teus irmãos. Gritando e marchando. "Abaixo o latifúndio! Abaixo a tirania! Viva a reforma agrária! Viva a liberdade!”.

recortamos as sequências em análise, extremamente produtivas. Não conseguiremos, no entanto, no espaço deste artigo, dar conta de sua amplitude, que nos pede um retorno ao discurso da Igreja sobre os comunistas, e, também, ao discurso comunista endereçado aos cristãos. E aqui, referimos, especificamente, o trabalho de Courtine (2009), Análise do discurso político. O discurso comunista endereçado aos cristãos, em que o autor nos mostra a complexidade da relação de contato-confronto entre FDs que, em nosso caso, implicará, tal como estamos vislumbrando, entender como o discurso religioso, e, com eles, a fé e Deus, veem-se convocados a participar nos modos de dizer de latifundiários e camponeses sobre o trabalho, a terra, a luta, observando, entre outras questões, como “a religião 'ópio do povo' cede lugar à religião como 'suspiro da criatura oprimida"” (COURTINE, 2009, p. 238). 
Que democracia é essa que assiste, posseiro, ao teu assassinato frio, que vê o teu sangue ensopando a terra que tu conquistaste com o teu machado e não vai ao teu socorro? Essa democracia ainda não é a tua. É do grileiro. Quantos rios de sangue ainda correrão por esse Brasil imenso até que a democracia reconheça que nenhum bom título de grileiro deve prevalecer sobre o teu título que é a tua própria vida?

Um fragmento da Carta de Alforria do Camponês compõe a SD (B) 2. Aqui se constitui um sujeito que enuncia do interior da FD do campesinato, representando uma das posições-sujeito que nela se conformam: tal discurso encarna as necessidades dos camponeses a ponto de fazer-se instrucional, no entanto, as pegadas deixadas no intradiscurso evidenciam que estão em posições-sujeitos diferentes os intelectuais organizadores do movimento (aqueles que podem mostrar o caminho, como se vê em SD (B) $3-\mathrm{Eu}$ te apontarei esses caminhos ${ }^{14}$ ) e os camponeses (aqueles a quem se busca educar/esclarecer) que recepcionam os dizeres da Carta de Alforria.

Há, na SD (B) 2, um jogo de palavras que distingue essas posições. Poderíamos delimitálas fazendo uma analogia com as pessoas do discurso: o sujeito que enuncia diz "Eu" e se instala em um "Nós" que o representa juntamente com os não camponeses. (eu te mando esta carta; És tu quem mata a nossa fome; És tu que nos veste) Esse constitui um "Tu" que representa os camponeses. (Tu és com os teus irmãos quase todo o Brasil; E a pátria te esquece; E o capanga te esmaga). Mesmo na diferença, é aquilo sobre o qual se fala que os une: o enaltecimento do ser camponês, a crítica ao latifúndio, a denúncia da escravidão dissimulada e a busca pela liberdade. Bem como a oposição a um "ele", conforme vimos na SD (L) 1, colocado no lugar do inimigo - aquele de quem "tu" és vítima.

Vale destacar, nesse recorte, a sequência em que se define a violência, "a violência é", diz esse sujeito que enuncia, produzindo um movimento de definição da violência que se faz como resposta ao discurso sobre a violência da liga:

A violência é: o capanga/a polícia/ a ameaça de te jogar fora da terral te pôr a casa abaixo/ te arrancar a lavoura/ te matar de fome/ te chamar de comunista/ dizer que Deus te castiga.

Impossível não retomar, aqui, a reflexão de Courtine (2009), em seu trabalho sobre o discurso comunista endereçado aos cristãos, em que aparecia "A violência, não é de nós que ela vem..../. Ao analisar essa frase contrastiva, Courtine (ibidem, p. 184) dirá que:

Se "varrermos" o interdiscurso da FD comunista, no qual fizemos figurar um certo número de sequências discursivas dominadas pela FD católica, poderemos aí encontrar sem esforço um conjunto de formulações em rede, com as quais a formulação de referência mantém uma relação interdiscursiva. Condensando seu princípio: a violência vem dos comunistas.

\footnotetext{
${ }^{14} \mathrm{O}$ forte atravessamento do discurso religioso nos boletins é algo que ainda merecerá, de nossa parte, maior detalhamento, o que não será possível nesse momento. Mas já se mostra muito produtivo no corpus um modo de dizer para o sujeito camponês que está fortemente marcado pela presença do discurso religioso cristão, visto que em enunciados como "Eu te apontarei esses caminhos.", toma a palavra esse sujeito que se diz a partir de um lugar da verdade, da iluminação, como se ouve, no Evangelho de João, as palavras de Jesus: "Eu sou o caminho, a verdade e a vida" (A BÍBLIA, JOÃO 14, 6).
} 
Podemos dizer, em nosso caso, que de um modo distinto, é também numa relação interdiscursiva com a FD do latifúndio, aqui representada pelo conjunto de recortes da mídia dominante na qual comparecem os saberes advindos dessa FD, que se pode compreender a formulação "A violência é X.", que aparece na sequência em análise, e que faz aparecer, pela ausência, o discurso da FD antagônica: a violência é o comunismo/comunista/as ligas.

Se o Deus e a violência, nos dizeres das duas FDs antagônicas, não são os mesmos, a Liberdade tampouco o é. Ela começa a ser evidenciada, sem que haja formulações a esse respeito, em contraposição aos grilhões do latifúndio. O acorrentamento a ele é tomado na FD do campesinato como o maior dos castigos. (Como se pudesse haver maior castigo do que esse em que tu vives. Acorrentado ao latifúndio.) Uma nova reivindicação/disputa por sentidos se instala aí: O que seria Liberdade para o latifundiário que por sua vez difere da Liberdade para o camponês?

A Liberdade para o latifúndio não é formulada. Entretanto, esse sentido se mostra pela repetibilidade, na FD do campesinato, por meio de uma assertiva: A Liberdade é..., evidenciando-se no trabalho da ideologia, que é exercida "na produção de evidências de sentidos, no movimento contraditório de reprodução/transformação das condições materiais de produção" (SOBRINHO, 2016, p. 95).

O latifúndio é, reiteradas vezes, mostrado como astuto, enganador, violento. Como aquele que mata o camponês de fome, priva-o de vestes, joga-o fora da terra, põe sua casa abaixo, arranca-lhe a lavoura. Eis o que compreendemos ser a prisão do Camponês e que, ao mesmo tempo, representa a liberdade para o latifúndio. Liberdade de dispor da vida e morte do camponês. É esse o motivo pelo qual, na FD do campesinato, afirma-se que o camponês não pode se submeter a uma liberdade que não é a sua. Liberdade para o latifúndio é morte para o camponês.

Liberdade para o camponês quer dizer terra. Quer dizer pão. Quer dizer casa. Quer dizer remédio. Quer dizer escola. (SD (B) 3). Isso é tudo o que o latifúndio não lhe oferta, por isso só pode ser conseguida através da luta, através da Liga, que terá como grande finalidade a união dos camponeses, união essa à qual se faz referência, em seu discurso, em várias ocasiões: ...eu te digo e repito: não adianta a viagem se tu fores sozinho. Convida teu irmão sem terra ou de pouca terra... (SD (B) 4), Sozinho és um pingo d'água, Ou simples grão de poeira, Mas unidos, teus irmãos, Tu formas uma cachoeira... (SD (L) 3).

Na SD (B) 3, a insistência em asseverar o que é a Liberdade, para o camponês, e quais são os caminhos para alcançá-la funciona a nosso ver, como um gesto de resistência, pois entendemos que

Há resistências nos discursos porque os sujeitos e a língua estão expostos à contradição, atravessados pela historicidade, marcados por um querer-dizer que expõe uma luta pela e com a palavra, uma luta pelos sentidos das palavras que pode ser também uma forma de resistir, para o sujeito, às palavras do outro. (DE NARDI; SOUZA, 2018, p. 552) 
E essa forma de resistir expõe as possibilidades de ressignificar a Liberdade na subversão de sua imagem e na construção de como consegui-la, desembocando na formação e manutenção das Ligas Camponesas. A Liga será, então, um caminho que levará o camponês à liberdade, pois sozinhos os que lutaram nunca conseguiram nada. Já se gritou demais. E nada. É que o grito veio de cima. De bem poucas vozes.

Ainda na SD (B) 3, na FD do campesinato, insiste-se em tomar para si o significado das palavras que normalmente são usadas, no discurso hegemônico, contra os camponeses. Quando olhamos para a formulação: Que democracia é essa que assiste, posseiro, ao teu assassinato frio, que vê o teu sangue ensopando a terra que tu conquistaste com o teu machado e não vai ao teu socorro? Vemos que aí existe a designação do camponês como posseiro, ou seja, é aquele que detém a posse da terra. Chama a nossa atenção a relação que se estabelece aqui entre os conceitos de Democracia e Posse, que tangenciam ainda o conceito de Propriedade.

Como, dentro de uma democracia, não se leva em consideração os atributos dos camponeses para que se possua a terra? Como pode ser ignorada a posse da terra pelos camponeses se ela foi conquistada pelo seu machado? Como o camponês pode pagar com a vida por querer estar na terra e cultivá-la? Não cabe na lógica do campesinato que um sistema se diga democrático e não leve em conta o clamor do seu povo por aquilo que o conceitua: ter o domínio da terra é um dos elementos que faz do camponês, Camponês. Reivindica-se aí um conceito não logicamente estabilizado para a Democracia, instalando-se, assim, um movimento de resistência que se caracteriza "pela heterogeneidade, pela incompletude, pelo estranhamento e pela opacidade" que perpassa a língua e o sujeito discursivo imersos na história (LEANDRO FERREIRA, 2015, p. $163)$.

A nosso ver, os boletins possuem, pela reapropriação de sentidos, pela injunção à luta, um efeito de transformação, que pressiona a bolha do capitalismo em uma sociedade que se compreende democrática, mas não entende que nenhum bom título de grileiro deve prevalecer sobre o teu título que é a tua própria vida. A carta de Alforria do Camponês põe em jogo "O aspecto ideológico da luta para a transformação das relações de produção" (PÊCHEUX, 2014, p. 5), trazendo à tona "novas relações de desigualdadesubordinação" (PÊCHEUX, ibidem), que rearranjam conceitos, deslocando-os dos seus lugares pretensamente estabilizados pelo trabalho dos Aparelhos Ideológicos de Estado, que marginalizam e condenam a luta do camponês pela posse da terra.

\section{FORJANDO UM PONTO FINAL: ESCLARECER, UNIR, LUTAR}

$\mathrm{Na}$ tentativa de forjar um ponto final para a reflexão que empreendemos nesse artigo vamos voltar a mais um recorte do jornal Liga e seus "Versos Camponeses". Nele encontramos, mais uma vez, um discurso que evidencia, dentro da FD do Campesinato, a voz do sujeito-camponês que fala, este camponês esclarecido, que, por estar neste lugar, possui a autoridade para falar aos outros camponeses, que são potenciais partícipes das Lutas pela terra. 
SD (L) 4

VERSOS CAMPONESES

(Liga 62. 12. 11 - Da carta aos camponeses do Brasil de Zé da Luz)

Sozinho és um pingo d'água

Ou simples grão de poeira,

Mas unidos, teus irmãos,

$\mathrm{Tu}$ formas uma cachoeira,

E o vasculho da miséria,

Deixarás na ribanceira.

E não exista obstáculo,

Onde tua força não vença,

$\mathrm{O}$ abismo da ignorância,

O lamaçal da desgraça,

O carrascal da miséria,

A podridão da doença.

A liberdade vem perto,

Já sinto os encantos seus,

Ela fala a meus irmãos,

Através dos versos meus,

Viva as ligas camponesas!

Viva o Brasil! Viva Deus!

O sujeito que enuncia nesses versos, jogando com as palavras, num processo de construção de antíteses, faz com que o "tu" singular se transforme em "irmãos", que juntos marcharão para vencer o latifúndio - aqui retratado pelas mazelas que impõe ao camponês: miséria, desgraça e doença. Ao invés de sozinhos, unidos; de pingo d'água, cachoeira... todos em busca de uma liberdade que só poderá ser alcançada através da união - o que justificaria, a rigor, a formação e manutenção das Ligas Camponesas no Brasil.

A propósito da manutenção das Ligas, entoam-se, no final do poema, palavras de ordem cujo efeito de sentido se assenta na exaltação e na inculcação daquilo que é caro ao camponês: as Ligas Camponesas, o Brasil e Deus. É a posição sustentada por aqueles que empregam as expressões: Viva as ligas camponesas! Viva o Brasil! Viva Deus! que nos faz depreender o seu sentido. Segundo Pêcheux ([1975] 1997, p. 147), as palavras e expressões "adquirem seu sentido em referência a essas posições, isto é, em referência às formações ideológicas nas quais essas posições se inscrevem." Por isso sabemos que, ao se dizer: Viva as ligas camponesas, por exemplo, há uma conclamação ao caminho que levará os camponeses à liberdade SD (B) 3 e não aos focos de subversão que poderão explodir quando menos esperarmos (SD 1).

As evidências de sentido - que se constroem quando da exaltação Viva o Brasil - resultam do efeito de evidência do sujeito (PÊCHEUX, [1975] 1997, p. 140) que enuncia no interior da FD do Campesinato. Viva o Brasil, longe de significar uma exaltação patriótica de direita $^{15}$ - como ocorreu na Alemanha nazista, quando circulava um dos enunciados

${ }^{15}$ Os enunciados Viva o Brasil! e Viva Deus!, hoje, deslizam para outra memória, a memória do "Brasil acima de tudo! e Deus acima de todos! - Slogan de campanha do atual Presidente Jair Bolsonaro, que bebe 
mais repetidos "Deutschland über alles", (que quer dizer "Alemanha acima de tudo".) inscreve-se num discurso que atribui ao povo, em sua maioria, ao povo camponês a formação do País: Tu és com os teus irmãos quase todo o Brasil. Ou seja, o país é o povo. E se o país é o povo, este precisa ter direitos que os façam se sentirem cidadãos. É um outro modelo de país que se exalta, não o Brasil do latifúndio.

Entendemos, então, neste enunciado, que aqui ocorre o mesmo que aconteceu com as palavras: Liberdade, Deus, Democracia... uma torção em seu sentido, que rechaça o Brasil das injustiças, da miséria e da violência; o Brasil que naturaliza crimes que "são praticados diariamente, pelos latifundiários, cuja polícia privada age sob as vistas complacentes e com a própria conivência da polícia do governo" (JULIÃO, 1962, p. 32). O Brasil da interjeição Viva o Brasil! reivindica o conceito de país com terra, pão, casa, remédio, escola e paz (SD (B) 3).

Nesse momento em que buscamos colocar um ponto final nessa reflexão, ainda esburacada sobre o discurso de/sobre a Liga Camponesa de Galileia, o que nos parece importante destacar é que é na reapropriação das palavras, em sua inscrição numa nova ordem do dizer, na torção dos sentidos das palavras construídos a partir da repetição de um discurso dominante sobre os camponeses e sua luta que se faz a resistência na Liga.

Se pela mídia dominante se fazia ouvir o latifúndio e o discurso de criminalização das ligas - urdido na repetição incansável do "comunista inimigo" e do "perigo" representado pelos vermelhos que ameaçavam "a paz no campo",- o desejo de educar/esclarecer/instruir materializa-se no boletim "Carta de alforria do camponês" e no jornal "A liga", espaços de escrita que o camponês esclarecido e os intelectuais do movimento encontram para responder a esse discurso sobre (MARIANI, 1998), produzido pela mídia, num trabalho de fazer emergir sentidos outros que possam convocar o sujeito à luta e legitimar sua ação.

\section{REFERÊNCIAS}

AZEVEDO, Fernando Antônio. As Ligas Camponesas. Rio de Janeiro: Paz e Terra, 1982. BÍBLIA SHEDD. Jesus conforta os discípulos. Trad. Bras. São Paulo: Vida Nova, 1997.

CHAYANOV, A.V. La organización de la unidad económica campesina. Buenos Aires: Nueva Visión, [1925] 1974.

COSTA, F. de A. Racionalidade camponesa e sustentabilidade: elementos teóricos para uma pesquisa sobre a agricultura familiar na Amazônia. Cadernos do NAEA, Belém, 29, 1-35, 1994. COURTINE, Jean-Jacques. Análise do discurso político. O discurso comunista endereçado aos cristãos. São Carlos: Edufscar, 2009.

DE NARDI, F.S.; SOUZA, F.F.N. de. Sobre a arte de resistir: os jogos na/sobre a língua na arena do rap. Em: ABRAHÃO E SOUSA, L.M. et. al. (Orgs.). Resistirmos, a que será que se destina? São Carlos: Pedro \& João, 2018. p. 545-567.

DE NARDI, F.S.; NASCIMENTO, F.A.S. do. A Propósito das noções de resistência e tomada de posição na Análise de Discurso: movimentos de resistência nos processos de identificação com o

na fonte do Slogan da campanha nazista de Hitler (Alemanha acima de tudo). Isso nos faz refletir sobre o que nos disse Pêcheux (2014, p. 7) quando afirmou que "as formações ideológicas se referem aos objetos... ao mesmo tempo idênticos e diferentes... o próprio da luta ideológica de classes...num mundo que, de fato, não termina nunca de se dividir em dois." 
ser paraguaio. Signum: estudos da Linguagem. Londrina, v 19, n. 2, 2016. Disponível em http://www.uel.br/revistas/uel/index.php/signum/article/view/25109.

FORMAN, S. Camponeses: sua participação no Brasil. Rio de Janeiro: Centro Edelstein de Pesquisas Sociais, 2009. Disponível em SciELO Books (http://books.scielo.org).

IANNI, O. Relações de produção e proletariado rural. Em: SZMRECSÁNYI, T.; QUEDA, O. Vida rural e mudança social. São Paulo: Companhia Editora Nacional, 1976.

JULIÃO, F. Carta de alforria do camponês. Em: A questão agrária no Brasil - história e natureza das ligas camponesas: 1954-1964. São Paulo: Expressão Popular, 2012.

JULIÃO, F. Cambão. Cuernavaca, ME: Cidoc: Centro intercultural de documentación, $\mathrm{n}^{\mathrm{o}}$ 13, 1970.

JULIÃO, F. Periódico Liga. Em: Ligas Camponesas. Cuernavaca, ME: Cidoc: Centro intercultural de documentación, $\mathrm{n}^{\circ}$ 27, 1969.

JULIÃO, F. Que são as ligas camponesas? Rio de Janeiro: Ed. Civilização Brasileira, 1962.

KROEBER, Alfred. Em: FORMAN, S. Camponeses: sua participação no Brasil [online]. Rio de Janeiro: Centro Edelstein de Pesquisas Sociais, 2009.

LEANDRO-FERREIRA, M.C. Resistir, resistir, resistir... Primado prático discursivo!. Em: SOARES, A.F. et. al. (Orgs.). Discurso, Resistência e.... Cascavel: EdUnioeste, 2015. 159-167. MARIANI, B. O PCB e a imprensa. Os comunistas no imaginário dos jornais. 1922-1989. Rio de Janeiro: Revan; Campinas: Editora da UNICAMP, 1998.

NEVES, D.P. Diferenciação sócio-econômica do campesinato. Ciências Sociais hoje, Anpocs, São Paulo, Cortez Editora, 1985. p. 220-241.

PÊCHEUX, M. (1975). Semântica e discurso. $3^{\text {a }}$. ed. Campinas: Ed. da UNICAMP, 1997.

PÊCHEUX, M. Ousar pensar e ousar se revoltar. Ideologia, marxismo, luta de classes, Décalages, vol. 1, iss. 4, 2014. Disponível em https://scholar.oxy.edu/decalages/vol1/iss4/15.

SILVA SOBRINHO, H.F. Michel Pêcheux e a crítica ao capitalismo: é preciso ousar se revoltar. Em: DE NARDI, F.S.; GRIGOLETTO, E. (Orgas.). A Análise do Discurso e sua história: avanços e perspectivas. Campinas: Pontes, 2016. p. 89-103.

WOLF, Eric R. Revoluções Sociais no campo. Em: SZMRECSÁNYI, T.; QUEDA, O. (Orgs.). Vida rural e mudança social. São Paulo: Companhia Editora Nacional, 1976.

Artigo recebido em: out. de 2019.

Aprovado e revisado em: nov. de 2019.

Publicado em: dezembro de 2019.

Para citar este texto:

SOUZA, Fabiana Ferreira Nascimento de; DE NARDI, Fabiele Stockmans. Sobre luta, educação e trabalho no campo: um olhar sobre os boletins da Liga Camponesa de Galileia. Entremeios [Revista de Estudos do Discurso, ISSN 2179-3514, on-line, www.entremeios.inf.br], Seção Estudos, Programa de Pós-Graduação em Ciências da Linguagem (PPGCL), Universidade do Vale do Sapucaí (UNIVÁS), Pouso Alegre (MG), vol. 20, Especial, Dossiê "Língua, discurso e trabalho na contemporaneidade", p. 139-157, dez. 2019.

DOI: http://dx.doi.org/10.20337/ISSN2179-3514revistaENTREMEIOSvol20pagina139a157 